Central Washington University

ScholarWorks@CWU

All Faculty Scholarship for the College of Education and Professional Studies

$1-17-2019$

The Agricultural Deities of Q 'Eqchi' Mayas, Tzuultaq'as:

Agricultural Rituals as Historical Obligation and Avatar of the Cultural Reservoir in Rural Lanquín , Alta Verapaz, Guatemala

YiShan Lea

Follow this and additional works at: https://digitalcommons.cwu.edu/cepsfac

Part of the Folklore Commons, Indigenous Studies Commons, Latin American Languages and Societies Commons, and the Religion Commons 


\author{
THE AGRICULTURAL DEITIES OF Q'EQCHI'
} MAYAS, TZUULTAQ'AS: AGRICULTURAL RITUALS AS HISTORICAL OBLIGATION AND AVATAR OF THE CULTURAL RESERVOIR IN RURAL LANQUÍN, ALTA VERAPAZ, GUATEMALA

\author{
YISHAN LEA \\ Associate Professor, Ed.D \\ School of Education \\ Central Washington University \\ 400 E. University Way \\ Ellensburg, Washington, 98926 USA \\ e-mail: yishan.lea@cwu.edu
}

\begin{abstract}
This study, based on fieldwork in rural Lanquín, Guatemala, discusses cultural continuity and the sense of historicity through agricultural rituals and worship of the agricultural deity Tzuultaq'as. The place, Lanquín, and the Q'eqchi' Maya peasant farmers are situated within a two-fold tension and contradiction. Geographically remote in relation to the economic centers in Guatemala, and marginal in infrastructural development, while their cash crop harvests never fail to be effected by the fluctuations of the global market. From the eclectic stance merging both theories of cultural essentialism and constructivism, by juxtaposing the emblematic event of the anti-Monsanto Law movement in 2014 in Guatemala, and by the calendrical cycles of ritual events, routines, and ceremonials in rural Lanquín, the subsistence practices of milpa (corn field) cultivation emerge as a central theme for cultural survival and continuity. The aggregated clusters of ritual processions and the system of symbolism used manifest the Q'eqchi' peasant thought and practice of sustainability and conservancy in their construction of a modern cultural identity that maintains congruency with the cultural essence of a nativist identity.
\end{abstract}

KEYWORDS: Maya cosmology • Q'eqchi' agricultural rituals • Tzuultaq'as • San Agustin Lanquín • Guatemala

\title{
IN T RODUCTION
}

In recent decades, the neoliberal political economy has swept across the world. New market places emerged, and previous economic systems integrated into a larger one. The speed of cultural inter-change and financial transactions has broken new ground. As a result of the shrinking globe, nation-state border lines are becoming increasingly 
blurred; under the umbrella of global development, local markets have widened to seek higher exchange values; as economisation expands across space, commodification through cultural appropriation has transgressed from the material and the tangible to the abstract and epistemological. Under the influence of technological machinery, we have seen an increasing number of indigenous communities and tribes rise in collective defence of their native commonwealths and aboriginal bio-diverse spheres. As the political and economic mainstreams manoeuvre their proxies, transnational corporations, the neoliberal foot soldiers of the invented world of the Internet, land in the Maya peasant communities with shining gadgets made by Samsung, Apple, and Huawei.

Indigenous activism and motivations are not haphazard, incidental or reactionary, nor are they voluntary captives of their traditions, associated with backwardness in the eyes of cultural others. The two power paradigms are encountered once again, this time in the Ladino dominant political arenas. The Monsanto Law (Ley Monsanto) granted exclusive intellectual rights to genetically modified maize seeds to the bio-tech company Monsanto. Other clauses of this law prohibit creole seeds as a result of natural cross-pollination and deter (and even threaten to outlaw) maize seed exchanges, a common practice that has traditionally existed among the indigenous communities (Lea 2017: 2664-2668). The Mayas have survived the colonial era, deculturalisation, and genocide during internal conflict; their milpa system, corn fields, has sustained the life force that cultivates it. Through the inter-cropping of chili peppers, beans, squash, and herbs, milpa provides other nutritional needs. Milpa also nourishes a cultural symbolism with which the people's indigenous identity intertwines.

For rural peasants the Maya ways of life that emerged from the subsistence-based economy of milpa provide a stark contrast to the economic model of mono-agriculturalism. Through massive production and market invasion, the technologised economy of neoliberalism engineers for profit, extracts resources, and accumulates wealth while asserting its dominance over the globe. In 2014, outside the Congress Hall and on the streets and major highways of Guatemala, the two ideologies duelled in a series of organised protests, strikes and blockages. The indigenous peasants invested in recurring and prolonged efforts to finally close in on indifferent Guatemala politicians and legislators and their neoliberal economic plans, which were poised to supplant the traditional milpa system on which the Mayan peasant way of life and being were constructed and depend.

For the impoverished peasant farmers in Guatemala, milpa constitutes a subsistence-based economy in which a universe of the indigenous consciousness is encapsulated. Q'eqchi' peasants, Milpa cultivation, and the situated bio-physical world weave a cultural narrative in which the semantic roles of agent, action and theme for meaningmaking are embedded. Structural roles articulate an intimate link between cultivation and maintaining the indigenous autonomy of a cultural community through control of the means of production. Cultural agency is expressed in the union of the Q'eqchi' as land cultivators and caretakers of nature. As subsistence farmers, the Q'eqchi' peasants differ from commercial farmers; land and organised labour are regarded as common wealth to guarantee collective survival. 


\section{CULTURAL LOGIC: CONVERGENCE OF THE CORPOREAL, THE BIO-PHYSICAL AND THE METAPHYSICAL}

Cultural survival and sustainability require one another in the historical construction of cultural communities. Both cultural models involve material conditions and metaphysical qualities in a dialectic as contingencies for cultural continuity. Edward Fischer (1999) proposes the concept of cultural logic to explain the dynamics of cultural essence and constructivism for the cultural continuity of an eclectic complementary quality. He defines cultural logic "as generative principles expressed through cognitive schemas that promote intersubjective continuity" (ibid.: 478). Cultural logic, as a social construct, is expressed through processes of socialisation and internalisation in personal and conventional mental models, according to Bradd Shore (1996: 47).

Cultural logic, like glue, coheres the structures of relations and of meaning. It brings a community into a cohesive whole, unifying, signifying, and drawing from the shared common fund of epistemology. Cultural logic underlies the ideological assumptions in cultural and political institutions. That is, the representations, tools and symbols are paradigmatic as institutions and as a consistent power apparatus. At the same time, the cultural institution produces meaning, generates associations and social referents, and governs social relations. Hence, behavioural patterns and cultural epistemology are reflective of common cultural expectations the boundaries of which are delimited by cultural logic. In these "structural paradigms" (Fischer 1999: 479), people construct and conventionalise their ways of sense making, consciously or not, or perform cultural actions in events, routines, and associated literal and metaphorical referents. Part cultural essentialism, part constructivism, Bruce Kapferer (1988: 211) acknowledges the converging quality of both historicity and agency in cultural continuity, affirming that "no tradition is constructed or invented and discontinuous with history". Hence, for Fischer (1999: 477), "cultural logic changes, but it does so in a manner internally consistent with that logic itself".

The abstract and generative principles of cultural logic for sense making resist change and persist "because of what they distilled ontologically" (Kapferer 1988: 211). In events through symbols, "they condense a logic of ideas, reflective of people's consciousness," (ibid.) metaphorically and materially grounded in the recurrent intertextual reading of experiences. Cultural agents project visions symbolically through performance to construct meaningful reality within the limited material conditions in which they find themselves ontologically. The Maya nativist stance affirms that, spiritually and cognitively, "there is a metaphysical quality to Mayaness that transcends the minutiae of opportunistic construction to unite individuals and communities across both time and space" (Fischer 1999: 477). This ontological need for meaning-making "tunes human actions to an envisaged cosmic order and projects images of cosmic order onto the plane of human experience" (Geertz 1985 [1973]: 90). The Maya cosmology is more than a nostalgic antiquity or a gleaned cultural essence; it is a cultural marker of consciousness for identity that is "materialized and constructed in the contemporary time and space" (Toohey 2013: 171). Jason Toohey notes that cultural consciousness marks identity materially and metaphorically "guides quotidian experiences, in which the ideational maps and topographies of worldview are mapped onto geographies and anchored in the lived experience of societies" (ibid.). Hence, the concept of cultural logic 
results from both the ontological plane of consciousness and geo-material experiences. This intersectionality yields a particular cognitive schema of meaning, values, associations, signs, symbols and systems. Clifford Geertz (1985 [1973]: 90) acknowledges the dual action of a physical and metaphysical world of consciousness attributed to cultural construction and continuity.

Cultural consciousness as a social construct results from the shared spatial and temporal domains of "habitus" (Bourdieu 1977 [1972]) and the engaged "modalities of structuration" (Giddens 1984). These productive systems of meaning as shared referents for resources, experiences, and relationships are all present in the conceptualisation of shared culture and identity that binds the individual with and in a community (Fischer 1999: 477). Karen Bassie-Sweet (1991), Dennis Tedlock (1993), Linda Schele and Peter Mathews (1999), Brent Woodfill (2011), Ruud Van Akkeren (2012), and many others, in deciphering pyramid inscriptions and topographical patterns of settlements, link the cosmological features and Mayan creation mythology to political ideology in the manifestations of architectural power simulation, such as power edification, ascension and transition. The multiple dimensions and elements that map the cultural landscapes of consciousness are devised parcels of a cultural unity to channel, consult, and communicate with higher beings/authority.

The above seemingly oppositional paradigms, both the essentialist and the constructivist stances, are not mutually exclusive. Instead, they often play out in mutual support for indigenous interests. An example can be seen in the indigenous political activism in the anti-Monsanto movement in 2014, including a political discourse of resistance in organising and mobilising the communities in solidarity. The nativist historicity intertwined with the means of subsisting and sustainability reveals their sense of cultural essence in negotiating power and constructing conditions of reality in the anti-Monsanto maize seed movement. The cultural modification of adaptation, acceptance, or syncretism occurs if there is inter-cultural congruency. In contrast, political cultural discourse reveals central concerns that are often taken for granted or invisible. Carlos Lopez Sanchez's assessment is very telling regarding the structural contradiction of paradigms:

Although the [Monsanto] seed is improved for more productivity, integration [would be] possible, provided there is not structural cultural conflict, as a result, there is a cultural amalgam. But the problem is that if there is a contradiction, be it a chemical one or a conflict in the eyes of the users, all we're doing is making [cultural] identity disappear. (Quinzio and Mendivil 2015)

The anti-Monsanto movement of resisting the economics of poverty and marginality reveals a clarity and self-articulation of cultural essence in cultural continuity and events to maintain the indigenous identity of Mayaness. The bio-tech crops, based on an ideology of profiting from the techniques of genetic modification, are antithetical to the indigenous cultural essence in their theory and practice.

During my fieldwork in Lanquín in 2014, as activities, i.e. layered events, built on routines, culminated in ceremonials, the concept of milpa (corn field) aggregates clusters of calendrical events with episodic ritual processions that manifest Q'eqchi' peasant thought and practice relating to sustainability and conservancy. I have analysed elsewhere the unity of the indigenous nativism and constructivism of the Maya: "the 
agricultural rituals are as much historical obligations/motivation as they are the cultural reservoir in the role of community organizing toward the struggle for cultural sustenance of the Maya humanity" (Lea 2018).

\section{A LOCATION IN TENSION: LANQUÍN, ALTA VERAPAZ, GUATEM A L A}

Thomas Merton critiqued the degenerative model of the progress of development born from the paradigm of domination. According to John Wu (2000: 81), "In [the global trend] of blurring the distinction between science and technology/technique, we have gone from former broadly human concerns to the narrowly pragmatic, the useful, the 'can do' and the 'know-how' add to what is profitable and marketable". The concern of progress is reversed as the frontier of progress is pushed from where science has previously gone to how far it can take humans with the technique (ibid.). Following the K'iche's defeat by Pedro de Alvarado's army in 1524, evangelical pacification relayed the mission of conquest when the Spanish military was blunted by the Q'eqchi' Mayas who occupied the Land of War, now the departments of Verapaces. From the time of the first cultural contact to contemporary times, the process of conquest has endured and continues.

The rural Q'eqchi' peasant farmers in Lanquín, Guatemala, are situated within a two-fold tension and contradiction of geography and economy. The location is relatively remote and economically marginal in relation to the capital, Guatemala City, and even in relation to its local capital, Coban, on the Guatemala highland of Alta Verapaz. In the last ten years, the communication infrastructure has outpaced the increasing need for clean water, electricity and sewage or sanitary systems, paved roads, medical cares, etc. However, their cash crops of cardamom, achiote and cacao never fail to be effected by movements in the global market. The middlemen arrive for their harvests, weigh them, and price them, and then throw them onto the truck beds of pick-ups. The raw materials are then transported on Guatemalan highways and embark on an export journey to overseas metropolises. For the maize harvest, it is a different story. Their biannual seasonal harvest stays with and feeds the families.

\section{De/Codification of Tzuultaq'as}

Maya nativism invokes imagery of the god of maize using a series of clusters of symbols, rituals, ceremonies and routines in daily living. The Maya creative mythology, Popol Vuh, delineates the dawning of the Maya consciousness of the world. In the midwife's hands, the maize dough, the prime ingredient, was moulded into the corporeal form of the Maya's ancestors. Maize takes a theological determinist role wherein the union of both physical and metaphysical beings is encapsulated and whereby the corporeal body subsists. In turn, the humanity of maize immortalizes the self in the labour of maintaining/cultivating milpa (corn field). Maize, an essentialised code, is a multivocal sign of multiple meanings (Turner 2009 [1969]: 50). In twinship, the protagonists the maize god and the offspring fought and were sacrificed in the infra-world many 
time but were resurrected and transformed within the tension of duality from death to living, transitioning from dark to light. In these episodes, the protagonists and antagonists engaged in tensions and struggles that were set off by the properties of complementary pairs and duality of opposites. At the centre of Q'eqchi' subsistence practice is the structural unity of the consciousness of duality. At the same time, the omnipotent agricultural deities, Tzuultaq'as, reign over ethical relations.

The conceptualisation of Tzuultaq'a can be traced to the K'iche' creation mythology, Popol Vuh, commonly known as the bible of the Mayas. Akkeren (2012) cross-examined the intersectionality of tales of Tzuultaq'a with Popol Vuh. Tzuultaq'a represents a variant of the Xibalba. In a Q'eqchi' legend well known among my informants, and in the literature, La Historia de Sol y Luna, B'alam Q'e y Qana Po ('The Story about the Sun and the Moon, B'alam Q'e and Qana Po'), Tzuultaq'as are the morphed deities of Xibalbas (Akkeren 2012: 224-227). Maize symbolises life, which is a performance of miracles by Tzuultaq'as. In the legend, the sun, B'alam Q'e, disguised under the pelt of a jaguar, courted the moon weaver, and the couple later eloped. The moon weaver's father, a Tzuultaq'a, hunted down the rebellious duo. The sun hid himself under the shell of a turtle as the Tzuultaq'a emitted a lightning strike. The sun god escaped death, but the turtle shell was left with a cleft from the strike. This is the moment in Popol Vuh at which the maize god emerges and is resurrected.

The symbolism of life referencing maize, the miracle crop by Tzuultaq'as, is iconic for both K'iche' and Q'eqchi' in the above examples of Popol Vuh and the Q'eqchi' legend. As a main subsistence crop, maize is likened to an anthropomorphised representation that underwent transformation, vanquishing time and death. The Maya belief assigns "a supreme religious value on time as a passage of experience" (Wolf 1970 [1959]: 88) wherein material and spiritual lives intersect. Time regulates the trajectory of material being. The liminal time for transformation occurs in an agricultural epoch during the time "between depletion and renewed fertility of land" (ibid.). Similarly, Victoria Bricker (1981) observes that historical cycles are recurrent, but events do not repeat in the Mayan theology. Thus, changes are mediated through ritual processions that invoke the sacred union of Tzuultaq'a animism with endowed human labour and agency.

Many researchers have investigated the continuity of rituals and the worship of Tzuultaq'as in relation to Q'eqchi' historicity with regard to settlement, cultivation, wars and displacement. Abigail Adams (2001) investigated the historical configuration of power/authority encoded in the people's conceptualisation of Tzuultaq'a during the early period of the Guatemala republic. Q'eqchi' communities have negotiated shifting power centres from a localised representation of ancestral authority to a centralised governing structure dominated by Ladino elitism and shifts in interests focusing on the locally organised common wealth to a nationalised neoliberal economy. Richard Wilson (1995) documented the Q'eqchi' constructions of personhood, corporeal experiences and community relations, organised under an animistic belief and manifested in ritual events. Wilson further examined the ideological implications of cultural interruptions on the ritual continuity of the Q'eqchi' Mayas during periods of internal conflict. The spirit of Tzuultaq'a has managed to endure. As Stefan Permanto (2015: 76) observes in his fieldwork in the municipality of Chisec in Alta Verapaz, "the beliefs and ritual practices concerning the Tzuultaq'a were never completely eradicated". 


\section{RITUALS AS HUMAN OBLIGATIONS: MAYA CREATIVE THEOLOGY}

The first sowing commemorates the world's first dawning. A dialogue among the gods in Popol Vuh illustrates this occasion: "Let there be planting, let there be dawning... The time for the planting and dawning is nearing." (Tedlock 1996: 69) The sowing of the maize seeds under the celestial dome coincides with the appearance of Maya humanity and the awakening of agency. The gods urged, "For this we must make a provider and nurturer, can we be invoked and remembered on the face of the earth? Of our invocation, our sustenance, our recognition by human work, human design." (Tedlock 1996: 68-69) The relational epistemology (Bird-David 1999: S67-S91) is encoded in the embodiment of being in human design by the gods' creation. Humans cultivate the milpa as much as they cultivate Maya religiosity. Humans need gods as much as gods need humans. The mutual perpetuation of gods and humans is affixed on the matrix of the corporeal, subsistence and spirituality. Milpa cultivation is associated with a ritual model of remembering/invocation in the form of human obligations to the creator gods.

Victor Turner (2009 [1969]: 50) relates grammar, semantics and idioms as analogous to ritual constituency. Turner dissects ritual structure into a unit of event, episode, and ritual procession/progression through phases. Ritual symbolism embeds meanings, which have associated referents, carry their respective properties, and are clustered by semantic features. Like idiomatic languages, ritual performance encodes relations and confers roles to fulfil social expectation. Ritual functions include assimilating individual-collective cultural integration for relational harmony or simulating cooperation. In discussing twin birth for Ndembu in Africa Turner (ibid.) found that the Wubwang'u ritual as a coping strategy integrates the state of twin birth, a cultural biological anomaly, into the norm. Turner (ibid.) describes how what is called "plot" in the context of the Wubwang' $u$ ritual consists of "the unifying of a pair of opposites, dominantly expressed in symbols for male-female difference, opposition and union". Turner's axis of the Wubwang'u ritual manifests a structural style organised in complementary or polarised and dualistic semantic poles.

The following delineates the language of the sowing of the maize seeds. The ritual procession sustains several episodes over a duration of days in various locations involving various or inter-village households of participants engaging in the ritual plot of duality during the critical sowing season. I will discuss three important episodes for the sowing ritual and examine each in turn with references to its symbolism.

\section{Rituals of Sowing Initiation}

Domingo, a carpenter from Nueva Esperanza who was 30 years old and married, talked about what was necessary for a man to perform the sowing initiation:

For me, I still do not know how to conduct the initiation. I'm married [but have no children yet]. I still do not have direct experiences in initiating the sowing of maize. [So] my father plants the seeds in my milpa for me. [When I'm ready], he [my father] will make me pay attention to how to do the sowing [ritual]. Now I still 
enjoy being together with my wife and telling jokes. [...] The language/the tongue also carries/has a dark side, as we put it. Sometimes the talk is crazy. For these [reasons], my father has not permitted me to do the sowing. [...] It depends on how a man conducts himself in life. Age is not important [to determine his readiness]. A man does what is required of him [in time].

Don Bex is the head of his household, which includes four generations living in two different huts in the same compound. Don Bex describes the ritual procession performed before and on the day of sowing initiation:

Prior to sowing, the man first conducts a ceremony and has candles lit in the temples. Then, back at home, he burns copal on the eve of sowing [as an offering to the deities, Tzuultaq'as]; before dawn, he grabs a planting stick to plant the maize seeds, as has always been done since the time of antiquity. (FM June 2015)

In my interview, Don Bex says in Q'eqchi', "I was born here, Rubehal, Lanquín. My parents were born in Sebach. I am 83 years old." The reference to his birth place, Rubehal, invokes both a cave, known as Rubehal, one kilometre away from his hut, and a Tzuultaq'a who supposedly resides in the place. Responding to my further queries about Tzuultaq'as, he explains, "Tzuultaq'a is our belief, different from yours. They are the owners of land." The term Tzuultaq'a encodes a two-fold semantic reference: animistic spirituality and dominant territories. He further explains, "Tzuultaq'as are how we name our mountains/hills, where there are rains, and the thunders are heard. Tzuultaq'as have different names, such as Rubehal, Saqik, and Sebach" (FM June 2015). Thus, where the Tzuultaq'a dominates or the mountain and valley meet invokes a personal and ethnic reference to one's origins.

On June 5 at 7 in the evening, in the dark imperceptible to an outsider's eyes and with only a few sparks in the kitchen hearth, Don Bex, despite old injuries, rose from his mat. He approached the kitchen hearth, from which he lit a white candle and passed its flame to ignite a copal pom in a brazier to make a fuming fire. He then approached the altar, where he managed to settle a white candlestick on a piece of tree bark in spite of his poor vision. Q'ana Rosa, the great-grandmother, brought in a full-grown turkey cloaked in black plumage and attached it to the side of the altar. Don Bex then commenced the ceremony, saying his prayers first at the altar. Continuing his prayers, he proceeded to step out into the pitch-dark orchard with the copal brazier dangling in his hand, wafting incense in different directions and finally concluding back at the altar.

The ceremony involves offering candles and burning copal pom as tribute to the Tzuultaq'as. The incense of the burning copal carries messages to the deities in prayers: "I'm pleading and I'm confirming. [...] And our copal is burning, so is the candle, which I am submitting to you as a gift to make the request for your permission." The prayers are to the Tzuultaq'as, who sustain human life with food and drink from the sacred plant, maize. Don Bex acknowledges in his prayers, "It is you, our Father-Mother; because of you I'm living the life you brought to me on the Earth since the time I was born and I grew with tortillas. This is what we always eat." (FM June 2015) The prayers meticulously name the Tzuultaq'as in Lanquín:

Our Father Saqehal, our Father Reubehal, our Father Saint Tomas, Father-Mother Chiaqeel, Father Chizubin. Our Father Saqehal, this land where we are going to 
sow. Father-Mother Setok, Father-Mother Ceiba, our Father Kamba, our Father Sechalum, Father-Mother Seku, Father-Mother Secomxic, this is our land, where we are going to sow our maize. (FM 2015)

The prayers imply the mental rehearsal of a drama to be performed under the witness of the spiritual owners of the land.

We are going to sow under our heaven and on our lands. Father-Mother Setok, Father-Mother Sechalum, Father-Mother Sejulsek, Father-Mother Kamba, the mountains-valleys where we will plant the maize seeds [...]. Ay, Dios, nothing would occur to my maize. Tomorrow, Saturday, at dawn I am going to sow on our land. We are going to sow in front of our mountain and will not encounter anything bad [...]. There will be harvests - one time, two times and three times - of our stars and our heaven. (FM June 2015)

In the prayers, the sowing of maize seeds is analogous to the sowing of the stars or to the seeds of the birth of human consciousness or of a universe. Carlos Rafael Cabarrús (1979: 109) says, "All worship [in essence] was an action that ultimately was recreating the world and was a response to the original acts as remembered in the legends".

The compound word Father-Mother is designated for "the first people who were made and modeled" by maize dough and who "had no mother and no father" (Tedlock 1996: 146). Thus, the stem word of Father-Mother is a referent for "symbolic androgynous parents" (ibid.), a union of duality that are life-giving and generative forces. Similarly, as an ideogram, Tzuultaq'a, referencing both mountain and valley semantically, encodes the people's ontological recognition of an omnipresent higher being. The union of mountain and valley in the linguistic code suggests a worldly articulation that combines the people's biophysical material situationality and their ontological consciousness.

On the eve of sowing the head of the household keeps a vigil throughout the night over the maize seeds. This individual passes the night near the altar upon which the maize seeds have been consecrated by prayers and incensed by copal. Throughout the night, the maize seeds remain in the candlelight because "the seeds cannot be without light," as affirmed by my informant.

\section{At Dawn}

The carpenter, Domingo, described the sowing process from memory based on his observation of his father performing the ritual.

At dawn, he arrives alone at his land. For three days, he suspends any [sexual] contact so that the maize seeds should grow well. [In the milpa], he begins to pray - I cannot recall the content of the prayers at the sowing initiation - he burns a little copal and lights a candlestick. Afterwards, he also provides a chicken as a gift to Mother Earth. He buries it well in the earth at a center point; in four pits to the center point, he plants approximately 15 or 12 maize seeds, known as the four corners of life [cuatro rincones de la vida]. At the center point, he has plunged his planting stick. Then, he goes home. (FM June 2015) 
I and his two great grandsons accompanied Don Bex at dawn on June 6. Barefoot as usual and slowed down by his physical condition and poor vision, Don Bex plodded along with the support of a tree sapling. From the main road, we turned into the woods. We crossed a stream and then climbed up to the other side of the riverbanks. From there, we maneuvered through muddy and slippery, wooded slopes and across valleys to ascend higher over several peaks.

The lone figure of Don Bex on the peak with his seed bag, his staff and his copal commemorated the footprints of his ancestors, as the ancestral journey is narrated in Popol Vuh: "[t]he first four mother-fathers [who] packed each one of the gods on their backs, [and hid the gods], 'Tohil,' 'Aulix,' and 'Hacauitz' [in the forests]" (Tedlock 1996: 158). The places in which they hid their gods were their dawning places where "[their] fathers had their sowing" (ibid.: 160). Popol Vuh recounts the same ritual of the multiplication of humanity on the gods' mountains: "[ $t$ ]heir dawning was there, and they burned copal there, incensing the direction of the rising sun. They came from there: it is their own mountain, their own plain [...]. They began their increase on that mountain." (Ibid.: 161)

In our time, on the mountain between heaven and earth, world creation is replicated. Upon arriving at the milpa, Don Bex worked with his machete to clear a small plot for the ceremony. From his seed bag, he took out copal and unwrapped its bananaleafed package. He brought the copal to the fire and lay it down amidst tree stumps and weeds. He then leaned forward, his elbow on one knee, with his footing supported by an exposed boulder. In a contemplative posture, he began to pray as if speaking with a vivid interlocutor, like an old friend. Between heaven and earth, where he stood at the near peak, his prayers mingled with the silence from the wilderness. The only audible sounds were birdcalls and buzzing insects in the vast silence.

Under the watch of the Tzuultaq'a Setok, the cane with which Don Bex walked functioned as a planting stick (estaque), a pre-Spanish farming tool. He plunged the estaque into the earth of weeds, tree debris and rocky boulders. Four times he did this, alternating the performance each time, with the other hand reaching for maize seeds from the seed bag slung over his shoulder. He visually counted the number of seeds in his palm, let maize seeds slide into the pit and smoothed out the pit with dirt and debris. There were four pits into which his estaque plunged in four directions around the centre point where he had laid the smoking copal at the beginning of the ritual. Upon completing the sowing of the seeds in the four corners, he plunged the estaque into the centre of the four corners of life. There his staff remained as "an axis uniting heaven and earth" (Girard 1962: 186).

Don Bex performed the chapok k'al ritual, meaning 'to grab the crop' (Wilson 1995: 102), or the chapoc pim ('to grab the mountain') in Q'eqchi' (Cabarrús 1979: 99). Research conducted in Chichipate, Guatemala (Carter 1969), describes the chapok k'al ritual as having a standing cross in the centre of the milpa, turkey blood sprinkled on the cross and four candles and incensed copal utilised to establish the ritual structure. The centre of the four cardinal points symbolises "the heart of the milpa - ram li c'al - ram coming from the Spanish anima, or soul" (ibid.: 42). Wilson's (1995: 103) study in Cahabon, which is one hour from Lanquín, suggests that the four corners "form a corral so the animal can't get in [...] [suggesting] containment and classification, defining the border of cultivated fields versus wild forest". Evon Vogt (1976: 58) characterised the rituals 
of the sowing initiation as "small-scale models of a quincuncial cosmogony." Vogt's observation approximates the pre-Spanish record, "The Ritual of the Four World Quarters" in The Book of Chilam Balam of Chumayel (Roys 2008 [1933]: 20-22). The sowing ritual invokes a distant time when the world was first created and formed in the shape of "four sides and four corners" from "the heaven [to] the earth" (Tedlock 1996: 63). The act of staking the four corners signifies the construction of the world in the shape of a house (Cabarrús 1979: 100).

A solitary Maya man arrives on his milpa to sow by performing the "to grab the crop" ritual at dawn before the arrival of his male crew. The ritual brings fertile masculinity, symbolised in the figure of the Maya male farmer, into union with the femininity represented in Xna'hichoch' "Mother Earth". Thus, Cabarrús (1979: 102, 109) suggests that the ritual performance of sowing "to grab the crop" is a "[symbolic] replica of world re-creation". Sowing maize symbolises the sowing of the constellation, as in the prayers of Don Bex: "There will be harvest - one time, two times and three times - of our stars and our heaven." The stars (or the worlds) and the mind are the results of the seeds of human consciousness. The ritual thus consecrates the subsistence model of the milpa system, in which the organising constructs of social relations, labour and land are generative and are sacred.

At the finale, Don Bex turned to us (we were all entranced by the ritual performance) and said "let's go" (yo'o). Due to his poor physical condition, Don Bex led us back home after the initiation. Typically, the owner of the milpa stays to wait for the recruited kin's arrival to finish the maize planting. On our way back, we crossed paths with the crew of kinfolk who were arriving to complete the sowing.

\section{Sowing Maize in Chicanuz, Lanquín}

On May 30, I joined Sebastian and his in-laws to plant maize in Chicanuz. Before dawn, a crew of kin members congregated for the occasion. Upon their arrival, the men, young and old (from 12 years old to their fifties), headed to the backyard to prepare their estaques. First, a sturdy sapling was taken from the woods, and the knots were shaved and smoothed with a machete. One end of the sapling was sharpened, similar to a pencil tip. An estaque can measure approximately a man's height in length, and its sturdiness for bearing pressure depends on various types of work and the textures of different types of soil. Some of the kinfolk brought metal caps to fortify the sharpened estaques. The skill of preparing an estaque requires hands-on practice from an early age; one child was observed preparing his estaque while his older cousins looked on and commented.

In a typical Maya Catholic household, prior to eating breakfast, xut (boiled maize dough) and ground cacao are offered to the gods or the Catholic saints on an altar, and the head of the household lights a candle and burns copal in an insensario ('censer') to consecrate the offerings. Because Sebastian's in-laws were Evangelicos or Protestant Christians, I was told they did not perform this ritual, although an insensario was observed under the altar and a velador ('glass candle') was lit on the altar. The head of the household, Sebastian's father-in-law, does not perform the sowing initiation as Don Bex did. Before we left for the milpa, Sebastian's father in-law mixed the maize seeds with powdered insecticide, which prevents the seeds from being eaten by worms before 
buds have a chance to emerge from the seed shells. Then, he distributed the seeds into the woven seed bags of each planter; each man came forward to receive his seed bag, and we were off to $a u k$, or to sow.

The family's milpa is approximately two acres bordered by the Little Cahabon River. The plot appeared to be thoroughly cleared and smelled freshly seared, and it was layered with black ashes of an even tone. The earth began to release vapor when the sun rose from behind the mountain and patiently released force to the Earth. The morning breeze gently carried the vapor over the horizon to dissipate into the air. Here, we were on sacred ground.

Sebastian's father-in-law positioned himself first among the twelve men to line up in a row. They stood apart from left to right and proceeded with the sowing task. First, they plunged the planting stick into the soil and wiggled it from side to side to pry open a pit on the ground. In a smooth motion, they reached for five seeds from the shouldered seed bag. Then, they let the seeds slide or trickle into the pit. They covered the pit and smoothed it over with the estaque. Finally, they repeated the process in a square that would eventually form two lines from the beginning to the end points. The sowing task was concluded by noon, when a feast awaited the men's return.

\section{The Feast}

In the Pop family, a crew of 15 male guest planters from 10 to 60 years old trickled in and sat on the benches against three wall partitions facing an altar. The feast commenced in a solemn manner. Don Nicolas, the head of the household, took his seat at the first place on the bench to the left of the altar. His eldest son, Crisanto, helped in both the kitchen and the main quarters distributing and serving food. The guests waited looking toward Don Nicolas solemnly. Don Nicolas lowered his head and in a low but audible voice said his prayers. When concluding the prayer, Don Nicolas said to the guests, "Eat" (uah'in) to commence the feast. During this time, no female members stepped over the threshold into the main quarter; they worked continuously in the kitchen and passed more replenishments to Crisanto, the male go-between. The procession underwent a gradual shift of mood from solemn, resting, and rested, then buzzing as the guest planters became more relaxed and desired more food.

The last performance involves packing xel (leftover food) into banana leaves. Each guest should not finish his food; instead, he should leave a small portion for xel to take home and share with his family, and the family members will typically ask for the $x e l$. If there is nothing left, your maize will not grow to fruition. The $x e l$, topped with additional tortillas over the assorted meats, is wrapped and tied up with pacaya palm leaves, mimicking the corn cloaked in green husks holding the corn silk. "The shape of xel should look full and robust," said an informant (FM June 2015). During this period, the seated guest planters shifted into a mode of spontaneous movement, extending arms to receive banana leaves from the hostess and getting up from their seats and stretching. The hostess crossed from the kitchen to distribute banana leaves, but otherwise, she remained at the margin of the main ritual space.

The procession that carries the ritual segregation of both sex and the symbolic union of duality is sustained into the mid-day festive lunch ritual when the guest planters 
are fed. It dissolves when the guest planters offer thanks to the host and to the saints on the altar, and then each guest individually takes leave by crossing over the threshold of the hut into the open space of the yard. Gender division is maintained to scaffold social spaces throughout the event, from the sexual abstinence of the household head to the solitary "to grab the crop" ritual performed before dawn, as in the example of the 83-year-old Don Bex. Including the lunch feast, the dichotomised structure is adhered to collectively. This observance of gender division is congruent with the conceptualisation of the world in duality, as in the ideogram of Tzuultaq'a: heaven-earth or mountain-valley, referencing the higher being or the universe, and "Father-Mother" for "symbolic androgynous parents" (Tedlock 1996: 146). The union of the lone Q'eqchi' farmer and the fertile earth reaches the culminating apex of a ritual procession after days of vigilance, during sexual abstinence between the man and his spouse, prior to the sowing initiation.

Accordingly, organised labour, social relations and the landscape adhere to a complementary logic of "divisions of cold/hot, wet/dry, mountain/valley, heaven/earth, life/ death, etc." (Sánchez Morales and Isunza Bisuet 2015: 3). These ritual symbolic elements similarly exhibit "properties of condensation, unification of disparate referents, and polarization of meaning" as found in Turner's (2009 [1969]: 51) study on Wubwang'u twinship ritual of Ndembu in Africa. At one semantic pole in the twinship ritual, Turner found "the referents are social and moral facts, at the other, to physiological facts." These symbols, according to Turner, are drawn "from many domains of social experience in association with their ethical evaluation". (Ibid.) The symbols in the Q'eqchi' sowing ritual also are congruent or compatible with the Q'eqchi' Maya cosmology contingent to their material social experiences. The overall logic and sense of historicity exhibit a theoretical convergence of cultural essentialism and constructivism.

\section{IN THE NAMES OF TZUULTAQ'AS}

The Q'eqchi' belief of Tzuultaq'as is overarching and omnipresent in consciousness. The Tzuultaq'as are personified deities, its embodiment abounds territorially.

Tedlock (1996) traced the topographical features in the Popol Vuh with the corresponding contemporary landscape in the Q'eqchi' dominant territory of Alta Verapaz. A geo-political sovereignty and autonomy of subsistence production are embedded in the Q'eqchi' community of villages and hamlets of Tzuultaq'as, which function as a cultural reservoir where language, myth, customs, history, and resources are reserved and represent the common wealth in collectivity. The agricultural deities, Tzuultaq'as, primarily reside in the centre of the clusters of the cultural markers that are accompanied by a slew of signs and symbols in ritual performances. The referent and its evocation, Tzuultaq'as, are steeped in both significant events and mundane routines of the consciousness of maintenance and continuity of the material-spiritual essence and economy. The milpa system, as the main means of subsistence production for the rural Q'eqchi' peasants in Lanquín, Guatemala, represents a model of moral economy that weaves relationships, production and labour into a cohesive fabric of cultural community.

In summary, the belief of Tzuultaq'a encapsulates the central concerns of the Q'eqchi' with regard to sovereignty, subsistence production and labour relations. Relatedly, the 
assigned status of roles and authority in households and the community are enmeshed in a deity-human interdependency, in which the Q'eqchi' agency is inserted in the names of Tzuultaq'as to control the means and ends of production. The belief of Tzuultaq'a is a perpetuating ideology to maintain the material life and spiritual being of the race. Congruent with Armand Mattelart's (1970: 15) observation, the indigenous ideology of the names of Tzuultaq'as functions vicariously as "a mode of determinant production that humans insert, which reflects the conditions of human existence" in time and with time. In essence, the belief of Tzuultaq'a as a cultural essence encodes identity, historicity and sovereignty for the full exercise of the indigenous nativism of the rural Q'eqchi'.

The nativist symbolism departing from Tzuultaq'as, the omnipotent agricultural deities, reigning over ethical relations, in Turner's (2009 [1969]: 51) words, "unite the organic with the sociomoral order, proclaiming their ultimate religious unity, over and above conflicts between and within these orders" which cultural logic delimits.

\section{NOTES}

1 The names of hamlets in Lanquín.

\section{SOURCES}

Fieldwork materials of the author, Summer 2014-2015.

\section{REFERENCES}

Adams, Abigail E. 2001. The Transformation of the Tzuultaq'a: Jorge Ubico, Protestants and other Verapaz Maya at the Crossroads of Community, State and Transnational Interests. - Journal of Latin American Anthropology 6 (2): 198-233. DOI: https://doi.org/10.1525/jlca.2001.6.2.198.

Akkeren, Ruud Van. 2012. Xib'alb'a el nacimiento del nuevo sol: una visión posclásica del colapso maya. Guatemala: Editorial Piedra Santa.

Bassie-Sweet, Karen. 1991. From the Mouth of the Dark Cave: Commemorative Sculpture of the Late Classic Maya. Norman, OK; London: University of Oklahoma Press.

Bird-David, Nurit. 1999. "Animism" Revisited: Personhood, Environment, and Relational Epistemology. - Current Anthropology (Special Issue: Culture - A Second Chance?) 40 (S1): S67-S91.

Bourdieu, Pierre. 1977 [1972]. Outline of the Theory of Practice. Cambridge: Cambridge University Press.

Bricker, Victoria. 1981. The Indian Christ, the Indian King: The Historical Substrate of Maya Myth and Ritual. Austin, TX: University of Texas Press.

Cabarrús, Carlos Rafael. 1979. La cosmovisión k'ekchi' en proceso de cambio. San Salvador: UCA/ Editores.

Carter, William. 1969. New Lands and Old Traditions: Kekchi Cultivators in the Guatemala Lowlands. Jacksonville, FL: University of Florida Press.

Fischer, Edward F. 1999. Cultural Logic and Maya Identity: Rethinking Constructivism and Essentialism. - Current Anthropology 40 (4): 473-500.

Geertz, Clifford. 1985 [1973]. The Interpretation of Cultures. New York, NY: Basic Books. 
Giddens, Anthony. 1984. The Constitution of Society: Outline of the Theory of Structuration. Berkeley, CA: University of California Press.

Girard, Rafael. 1962. Los Mayas eternos. Mexico: Librería Robredo.

Kapferer, Bruce. 1988. Legends of People, Myths of State: Violence, Intolerance, and Political Culture in Sri Lanka and Australia. Washington, DC: Smithsonian Institution Press.

Lea, YiShan. 2017. The Rural Q'eqchi' Maya Consciousness and the Agricultural Rituals: A Case of San Agustin Lanquin, Guatemala. - International Journal of Social, Behavioral, Educational, Economic, Business and Industrial Engineering 11 (11): 2673-2677. https://waset.org/publications/10008159/the-rural-q-eqchi-maya-consciousness-and-the-agricultural-rituals-a-case-ofsan-agustin-lanquin-guatemala (accessed October 7, 2018).

Lea, YiShan. 2018. Praxis of Cultural Sustainability: A Q'eqchi' Case of Cultural Autonomy and Resistance against the GMO Giant, Monsanto. - Journal of Theory in Action 11 (4): 44-73.

Mattelart, Armand. 1970. La ideología de la dominación en una sociedad dependiente: la respuesta ideológia de la clase dominante chilena al reformismo. Buenos Aires: Ediciones Signos.

Permanto, Stefan. 2015. The Elders and the Hills: Animism and Cosmological Re-creation among the Maya in Chisec, Guatemala. Doctoral Dissertation. Sweden: University of Gothenburg. http://hdl.handle.net/2077/39336 (accessed March 19, 2017).

Quinzio, Matias and Marcos Mendivil. 2015. Morir Sembrando Vida produced by Estrella Audiovisual. Youtube video available at https://www.youtube.com/watch?v=7CIxw70YK6I (accessed October 7, 2018).

Roys, Ralph. 2008 [1933]. The Book of Chilam Balam of Chumayel. Washington, DC: Carnegie Institute Press.

Sánchez Morales, Julio César and Alma Isunza Bisuet. 2015. El Rayo en la Literature de Tradicion Oral de Tsoltsiles y Tseltales de Chiapas. - Revista Razon y Palabra 20 (90): 299-313.

Schele, Linda and Peter Mathews. 1999. The Code of Kings: The Language of Seven Sacred Maya Temples and Tombs. New York, NY: Touchstone.

Shore, Bradd. 1996. Culture in Mind: Cognition, Culture, and the Problem of Meaning. Oxford: Oxford University Press.

Tedlock, Dennis. 1993. Breath on the Mirror: Mythic Voices and Visions of the Living Maya. New York, NY: HarperCollins.

Tedlock, Dennis, transl. 1996. Popol Vuh: The Definitive Edition of The Mayan Book of The Dawn of Life and The Glories of Gods and Kings. New York, NY: Touchstone.

Toohey, Jason L. 2013. Feeding the Mountains: Sacred Landscapes, Mountain Worship, and Sacrifice in Maya and Inca Worlds. - Reviews in Anthropology 42: 161-178.

Turner, Victor. 2009 [1969]. The Ritual Process: Structure and Anti-Structure. Piscataway, NJ: Aldine Transaction.

Vogt, Evon Zartman. 1976. Tortillas for the Gods: A Symbolic Analysis of Zinacanteco Ritual. Cambridge, MA: Harvard University Press.

Wilson, Richard. 1995. Maya Resurgence in Guatemala: Q'eqchi' Experiences. Norman, OK: University of Oklahoma Press.

Wolf, Eric. 1970 [1959]. Sons of the Shaking Earth: The People of Mexico and Guatemala, Their Land, History, and Culture. Chicago, IL: The University of Chicago Press.

Woodfill, Brent. 2011. The central role of cave archaeology in the reconstruction of Classic Maya culture history and highland-lowland interaction. - Ancient Mesoamerica 22 (22): 213-227. DOI: https://doi.org/10.1017/S0956536111000307.

Wu, John Jr. 2000. Technological Perspectives: Thomas Merton and the One-Eyed Giant. - The Merton Annual 13: 80-104. 